\title{
Cytotoxic Effects of Testosterone on Brain Cancer Cell Line (A172) in Cell Culture
}

\author{
Farahmandlou N, Nooroozi S*, Saberi B, Moulavi P
}

\begin{abstract}
Testosterone have been shown in many studies to have protective role against cancer. The main aim of this study was to assess cytotoxic effects of testosterone on brain cancer cells (A172) in cell culture. A172 cells were exposed to $0.001,0.01,0.1,1$ and 10 $\mathrm{mg} / \mathrm{ml}$ of testosterone solution. MTT assay was used to determine cytotoxic effects of testosterone. Our results indicated that exposure to $0.1,1$ and $10 \mathrm{mg} / \mathrm{ml}$ of testosterone led to significant decrease in viability compared to control cells $(\mathrm{P}<0.05, \mathrm{p}<0.001$ and $\mathrm{P}<0.001$, respectively). According to our finding, high doses of testosterone have cytotoxic effects on brain tumor cells in cell culture.
\end{abstract}

Index Terms - Testosterone, A172, Viability.

\section{INTRODUCTION}

Brain tumors are composed of cells that exhibit abnormal growth in the brain. The major areas of the brain have one or more specific functions. They can be benign (noncancerous, meaning that they do not spread elsewhere or invade surrounding tissue) or malignant (cancerous). Cancerous brain tumors are further classified as either primary or secondary tumors [1]. They are very harmful diagnoses and could change the patient lifestyle because of the symptoms that come with brain tumors. Also it can cause personality changes and certain types of body reactions [2]. Anabolic steroids are artificial versions of a hormone that is in all of us - testosterone. These steroids can affect the hypothalamus [3]. Steroid drugs are type of drugs used to relieve swelling and inflammation. Some steroid drugs may also have anti-tumor effects [4]. Although we know that anabolic steroids are bad for the heart, can increase fat deposits in blood vessels and they may also damage the liver [3]. It has been shown that increased levels of testosterone were associated with a 30\%-80\% increased risk of early death after cancer, but unchanged risk of incident cancer [5]. In this study, we exerted laboratory experimental research to assess cytotoxic effects of testosterone on brain cancer cell line (A172) in cell culture.

Nooshin Farahmandlou (PhD) is with Department of Molecular and Cellular Sciences, Faculty of Advanced Sciences \& Technology, Pharmaceutical Sciences Branch, Islamic Azad University, Tehran-Iran(IAUPS).

Sanaz Nooroozi *(Corresponding author)is with Department of Genetics, Genetic, Faculty of Basic Science, Islamic Azad University of Tonekabon Branch, Mazandaran, Iran

Behrooz Saberi is with Department of Microbiology, Faculty of Basic Sciences, Islamic Azad University of Tonekabon Branch, Mazandaran, Iran

Pooria Moulavi is with Department of Biotechnology, Faculty of Basic Sciences, Islamic Azad University of North Tehran, Tehran, Iran

\section{MATERIAL AND METHODS}

Different concentrations $(0.001,0.01,0.1,1$ and $10 \mathrm{mg} / \mathrm{ml})$ of testosterone were prepared and used in our study. A172 cells (brain cancer cell line) were purchased from National Cell Bank of Iran (Pasteur Institute, Tehran, Iran). Cells were grown and incubated in standard situation. Then, cells were sub-cultured into $75 \mathrm{~cm}^{2}$ flasks, 96 -well plates or 6-well plates. Cytotoxicity of different doses of the progesterone was assayed using MTT method. The MTT [3_(4,5_dimethylthiazol_2_yl)_2,5_ diphenyl- tetrazolium bromide] assay is a colorimetric assay for assessing cell metabolic activity [6] [7]. MTT a yellow tetrazole, is reduced to purple formazan in living cells [8]. When cells are incubated with MTT, the resulting optical density of the formazan product is dependent upon both the concentration of MTT and the incubation time [9]. MTT assays are usually done in the dark since the MTT reagent is sensitive to light [7].

Analyses were conducted using the SPSS 20 and ANOVA.

\section{RESULTS}

Our results indicated that exposure to $0.1,1$ and $10 \mathrm{mg} / \mathrm{ml}$ of testosterone led to significant decrease in viability compared to control cells $(\mathrm{P}<0.05, \mathrm{p}<0.001$ and $\mathrm{P}<0.001$, respectively). (Figure I).

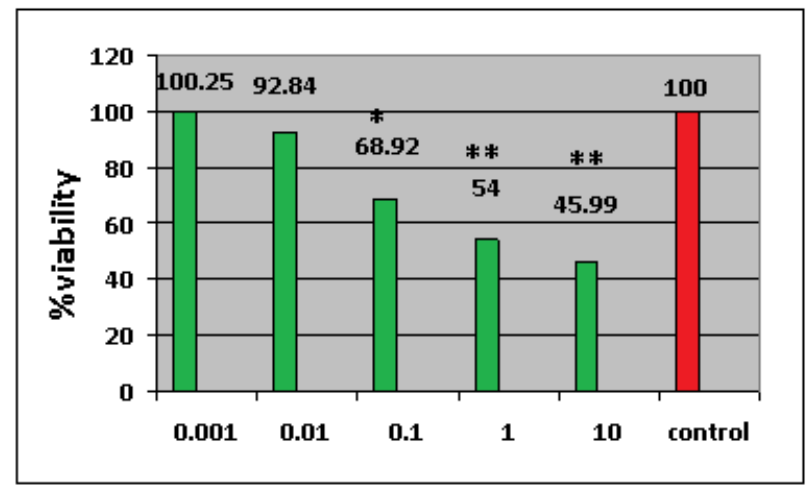

Figure I. Viability of A172 cells compared to control group. *and ** indicates significant difference compared to control group $(\mathrm{P}<0.05$ and $\mathrm{P}<0.001$, respectively).

\section{DISCUSSION}

Testosterone is a physiologically important androgen in both males and females but plays a significant role in the development of reproductive organs in the male. Testosterone acts via the androgen receptor which is a DNA-binding transcription factor which regulates gene expression and protein synthesis and plays a central role in increasing 
intracellular protein levels. As a result of androgen signaling, tissues proliferate and both basal metabolic demand and energy consumption increase [10].

Testosterone is a medication and naturally occurring steroid hormone. It is used to treat male hypogonadism and certain types of breast cancer [11]. In a study, the protective role of testosterone-repressed prostate message-2 (TRPM-2) has shown that is highly up-regulated in several tissues undergoing apoptosis, including normal prostate, and prostate and breast cancer xenograft models after hormone withdrawal. [12]. Testosterone has also been shown to decrease neuron differentiation in rat embryos. This action is mediated by the androgen receptor (AR), which is expressed in large numbers by rat neuron cells; nonetheless, such findings have not yet been reported in humans [13]. It has also been demonstrated that testosterone may promote early colonic adenomagenesis in rats [14].

\section{CONCLUSION}

According to our finding, high doses of testosterone have cytotoxic effects on brain tumor cells in cell culture.

\section{ACKNOWLEDGMENT}

We appreciate all who helped us to exert this study.

\section{REFERENCES}

[1] McNeill KA. Epidemiology of Brain Tumors. Neurol Clin. 2016 Nov;34(4):981-998.

https://doi.org/10.1016/j.ncl.2016.06.014

[2] McCabe MG, Valteau-Couanet D. Pediatric Cancers and Brain Tumors in Adolescents and Young Adults. Prog Tumor Res. 2016;43:74-86. https://doi.org/10.1159/000447075

[3] Angell P, Chester N, Green D, Somauroo J, Whyte G, George K. Anabolic steroids and cardiovascular risk. Sports Med. 2012 Feb 1;42(2):119-34.

https://doi.org/10.2165/11598060-000000000-00000

[4] Yi JH, Do IG, Jang J, Kim ST, Kim KM, Park SH, et al. Anti-tumor efficacy of fulvestrant in estrogen receptor positive gastric cancer. Sci Rep. 2014 Dec 23;4:7592.

https://doi.org/10.1038/srep07592

[5] Orsted DD, Nordestgaard BG, Bojesen SE. Plasma testosterone in the general population, cancer prognosis and cancer risk: a prospective cohort study. Ann Oncol. 2014 Mar;25(3):712-8. https://doi.org/10.1093/annonc/mdt590

[6] Appraisal of the MTT-based assay as a useful tool for predicting drug chemosensitivity in leukemia. Hayon T, Dvilansky A, Shpilberg O, Nathan I. Leuk Lymphoma. 2003 Nov;44(11):1957-62 https://doi.org/10.1080/1042819031000116607

[7] Sargent JM. The use of the MTT assay to study drug resistance in fresh tumour samples. Recent Results Cancer Res. 2003;161:13-25.

https://doi.org/10.1007/978-3-642-19022-3_2

[8] Sumantran VN. Cellular chemosensitivity assays: an overview. Methods Mol Biol. 2011;731:219-36. https://doi.org/10.1007/978-1-61779-080-5_19

[9] Weyermann J, Lochmann D, Zimmer A. A practical note on the use of cytotoxicity assays. Int J Pharm. 2005 Jan 20; 288(2):369-76. https://doi.org/10.1016/j.ijpharm.2004.09.018

[10] Gabrielsen JS, Najari BB, Alukal JP, Eisenberg ML. Trends in Testosterone Prescription and Public Health Concerns. Urol Clin North Am. 2016 May;43(2):261-71. https://doi.org/10.1016/j.ucl.2016.01.010

[11] Davis SR, Wahlin-Jacobsen S.Testosterone in women--the clinical significance. Lancet Diabetes Endocrinol. 2015 Dec;3(12):980-92. https://doi.org/10.1016/S2213-8587(15)00284-3

[12] Miyake H, Nelson C, Rennie PS, Gleave ME. Acquisition of chemoresistant phenotype by overexpression of the antiapoptotic gene testosterone -repressed prostate message-2 in prostate cancer xenograft models. Cancer Res. 2000 May 1;60(9):2547-54.

[13] Zhang L, Chang YH, Barker JL, Hu Q, Maric D, Li BS, et al. Testosterone and estrogen affect neuronal differentiation but not proliferation in early embryonic cortex of the rat: the possible roles of androgen and estrogen receptors. Neurosci Lett. 2000;281(1):57-60. https://doi.org/10.1016/S0304-3940(99)00942-8

[14] Amos-Landgraf JM, Heijmans J, Wielenga MCB, Dunkin E, Krentz KJ, Clipson L, et al. Sex disparity in colonic adenomagenesis involves promotion by male hormones, not protection by female hormones. Proc Natl Acad Sci U S A. 2014;111(46):16514-16519. https://doi.org/10.1073/pnas.1323064111 